\title{
IMUNITAS ALAMIAH: EOSINOPHIL EXTRACELLULAR TRAPS (EET)
}

\author{
Safari Wahyu Jatmiko \\ Departemen Patologi Klinik \\ Fakultas Kedokteran Universitas Muhammadiyah Surakarta \\ Correspondence to: Safari Wahyu Jatmiko \\ Email: safari.wahyu@ums.ac.id
}

\begin{abstract}
Eosinophils play a role in the defense against viruses, bacteria, fungi and parasites, as well as be involved in the pathogenesis of allergic and autoimmune diseases. The role of eosinophils in the defense against bacterial run by enzymes found in the granules such as MBP, ECP, EPO, and EDN, and spending EET. EET formation is determined by the presence of free radicals and intracellular calcium. The antimicrobial function of EET played by Histon.
\end{abstract}

Keywords: eosinophil, Eosinophils extracellular traps

Sistem imun alami adalah sistem imun yang sudah ada pada manusia sehat, mampu mengenali patogen yang masuk secara non-antigen spesifik, dan memberikan respons segera terhadap patogen tanpa adanya aktifasi sistem imun terlebih dahulu. Berbagai sel terlibat dalam sistem imun alamiah, diantaranya adalah sel eosinofil(Maddof dan Kasper, 2008; Warrington et al, 2011).

\section{EOSINOFIL}

Eosinofil adalah granulosit yang berukuran 12-17 $\mu \mathrm{m}$, inti berlobus 2-6 dengan sitoplasma biru pucat dan dipenuhi granula eosinofilik (Bain, 2011).Granula eosinofilik tersebut mengandung major basic protein (MBP),eosinophil cationic protein (ECP), eosinophil peroxidase (EPO), daneosinophil-derivedneurotoxin (Blanchard dan Rothenberg, 2009).

Eosinofil mengekpresikan berbagai molekul di permukaan membran sel nya. Diantara molekul tersebut adalah reseptor imunoglobulin untuk IgG (FcgRII/CD32) dan IgA (FcaRI/CD89), reseptor komplemen (CR1/CD35, CR3, dan CD88), reseptor sitokin (IL-3R, IL-5R,GM-CSF, IL-1aR,IL-2R，IL-4R，IFN- $\alpha$ R, dan TNF- $\alpha \mathrm{R}$ ); reseptor kemokin (CCR1 dan CCR3), molekul adhesi (very late antigen 4, a4b7, dan siglec-8), reseptor leukotrin (CysLT1R, CysLT2R, dan reseptor LTB4), reseptor prostaglandin, reseptor platelet-activating factor (PAF), dan TLRs (Stone, Prussin, dan Metcalfe, 2010).
Esoinofil mempunyai banyak fungsi. Beberapa fungsi diantaranya adalah:

1. Maturasi uterus

2. Pembentukan kelenjar mammae

3. Terlibat dalam seleksi negativdouble positive thymocytes

4. Presentasi antigen dan proliferasi sel $\mathrm{T}$

5. Sebagai regulator fungsi sel mast

6. Terlibat dalam imunitas terhadap infestasi cacing, infeksi virus, jamur, dan bakteri (Blanchard dan Rothenberg, 2009).

Meskipun eosinofil diyakini berperan dalam imunitas alamiah, akan tetapi fungsinya dalam melawan bakteri belum diketahui dengan jelas. Penelitian yang dilakukan yousefi et al (2010)menunjukkan bahwa lipopolisakarida dari bakteri gram negatif akan mengaktifkan eosinofil untuk melepaskan DNA mitokondria. Pelepasan ini tergantung dengan adanya reactive oxygen Species.Proses pelepasan DNA terjadi dengan cepat dalam waktu kurang dari satu detik. Di ruang ekstraselular, DNA mitokondria dan protein granul membentuk struktur ekstraseluler yang mampu mengikat dan membunuh bakteri.Sebuah proses yang sekarang dikenal dengan istilah EET (Simon et al, 2012).

\section{EOSINOPHIL EXTRACELLULAR TRAPS (EET)}

Pada tahun 2004, Brinkmann dan koleganya menunjukkan bahwa netrofil bisa 
mengeluarkan kromatinnya ke media ektraseluler dan mebuat ikatan dengan berbagai protein untuk membentuk netrophil extracellular trap. Hal ini terjadi ketika netrofil diaktifkan oleh phorbol myristate acetate, lipopolisakarida, interleukin 8,bakteri Gram positive, dan bakteri gramnegatif (Guimaraes-Costaet al, 2012). Kini diketahui bahwa sel-sel yang lain seperti basofil, sel mast, monosit, makrofag, dan eosinofil juga memiliki kemampuan yang sama (Goldmann dan Medina, 2013). Pada eosinofil, proses tersebut dinamakan EET (Simon et al, 2012).

Eosinophil extracellular trapmerupakan bagian darirespon imun bawaan dan dapat ditemukan pada beberapa keadaan seperti infeksi, alergi, dan penyakit autoimun. EET terdiri dari anyaman serat DNA (Deoxyribo Nucleic Acid) dan protein granul eosinofil seperti MBP dan ECP. Deoxyribo Nucleic Acid dalam EET berasal dari mitokondria eosinofil. Hal ini yang menyebabkan eosinofl tidak mengalami kematian setelah mengeluarkan EET (Yousefi, Simon, dan Simon, 2012). Meskpiun demikian, Ueki et al (2013) melaporkan bahwa sumber DNA EET juga bisa berasal dari inti sel. Ia juga membuktikan bahwa eosinofil yang mengalami EET pun bisa mati.

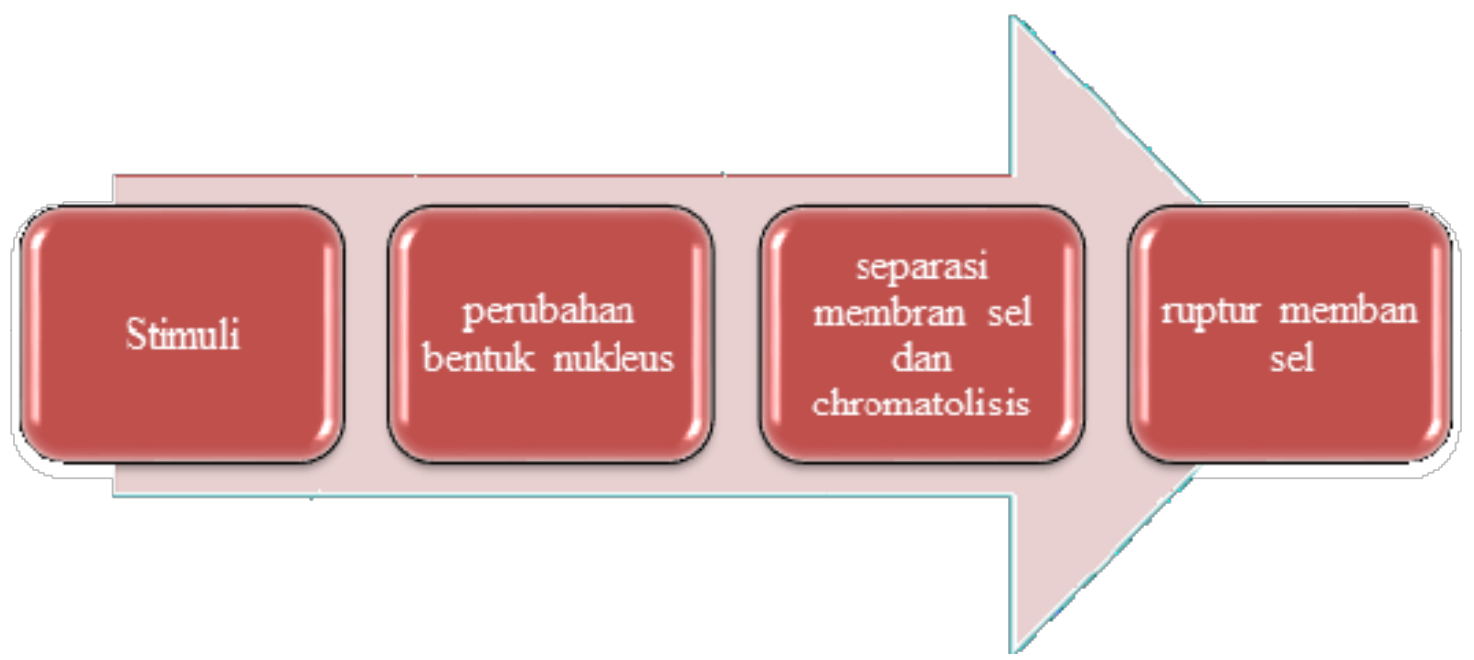

Gambar 1. EET yang disertai dengan kematian sel

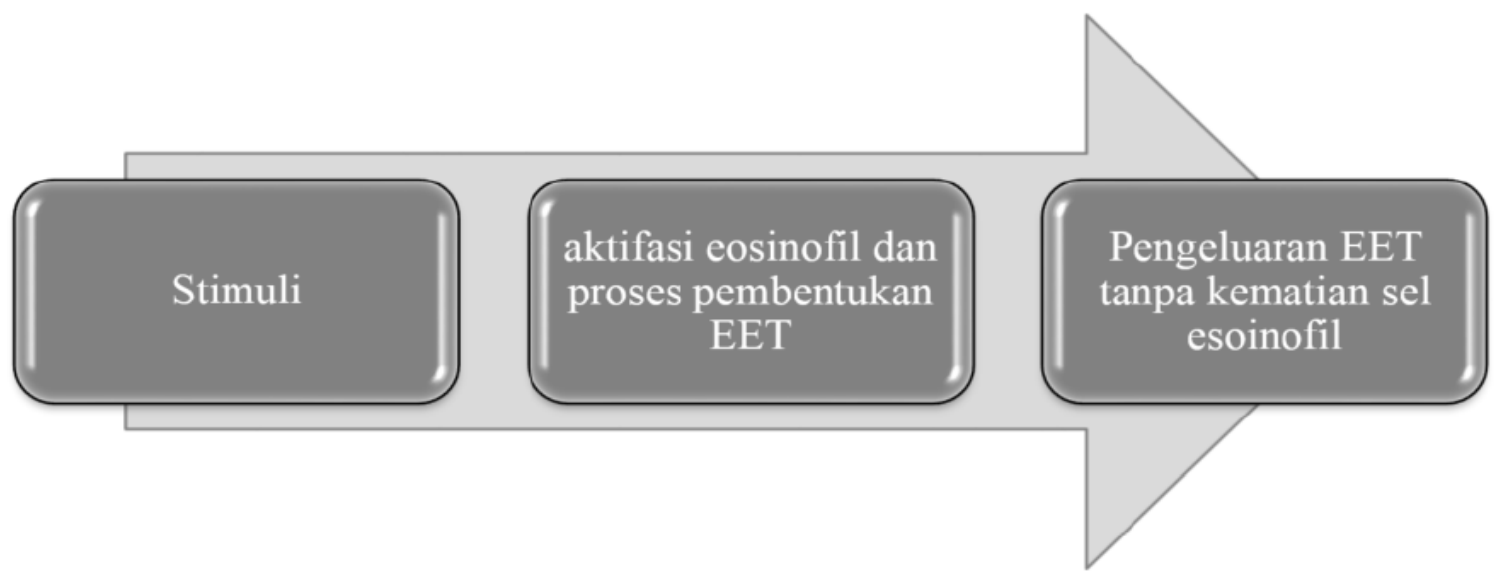

Gambar 2. EET yang tidak disertai dengan kematian sel

Eosinofil dapat diaktifkan oleh banyak hal. Toll like receptor, sitokin, kemokin, dan reseptor adhesi bereperan sebagai inisiator aktivasi eosinofil. Bila eosinofil telah aktif, maka terjadi serangkaian proses yang akan memicu terbentuknya EET (Chunet al, 2007; Morshedet al, 2012; Yousefi, Simon, dan Simon, 2012). Aktifasi eosinofil memicu teraktifkannya Protein 
Kinase C (PKC) (Kato et al, 2005). Setelah PKC aktif, ia akan merangsang enzim NADPH oksidase (In-Heeet al, 2014). Hasil dari aktifnya NADPH oksidase adalah terbentuknya $\mathrm{O}_{2}^{-}$. Selain pembentukan radikal bebas, aktifasi eosinofil juga mengakibatkan peningkatan kalsium intrasel. Peningkatan ini akan mengaktifkan PAD4. Ketika
PAD4 aktif maka ia akan mengubah histon menjadi tersitrulinasi. Radikal bebas dan histon yang telah mengalami sitrulinasi ini kemudian mengakibatkan terjadinya kolaps nuklear dan disintegrasi membran sel. Hasil akhir dari proses ini adalah dikeluarkannya EET (Goldmann dan Medina, 2013; Guimaraes-Costaet al, 2012).

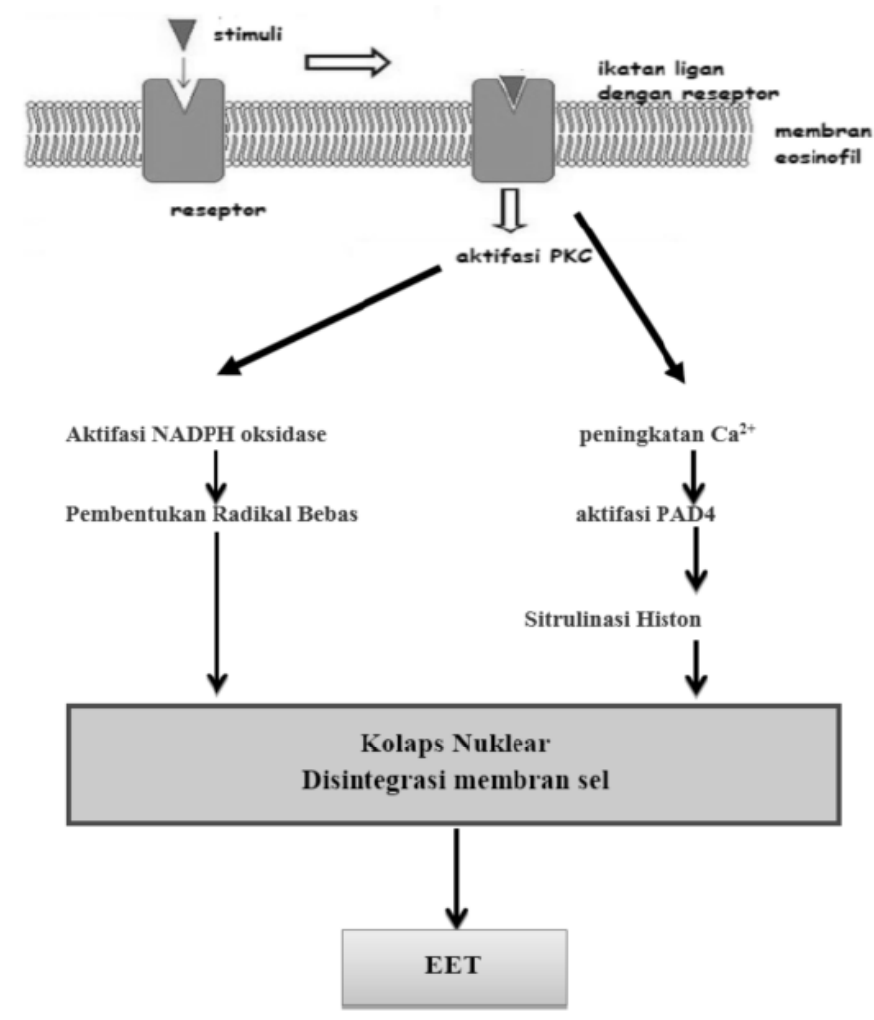

Gambar 3. Proses Terjadinya EET.

Pada awalnya EET ditengarai hanya berperan dalam imunitas terhadap bakteri saja. Akan tetapi sekarang EET diketahui mempunyai peran yang lain diluar imunitas terhadap bakteri. Sebagai contoh adalah EET terlibat dalam penyakit kulit inflamasi baik karena infeksi maupun non infeksi dan terutama pada sindroma wells (Simon et al, 2012). Bahkan diketahui juga bahwa EET terlibat dalam patogenesi penyakit asma bronkiale (Dworskiet al, 2011).

Pada konteks penyakit infeksi, EET diyakini sebagai strategi yang dikembangkan oleh sel inang untuk mengontrol dan mengeliminasi patogen. Sejumlah bakteri, fungi, dan parasit dilaporkan terjebak dan dibunuh oleh EET. Mekanisme molekuler bagaimanakah EET membunuh mikroorganisme belum diketahu dengan pasti. Banyak hipotesis diajukan untuk menjawab pertanyaan ini. Salah satunya adalah interaksi elektrostatik antara EET dengan permukaan bakteri. Setelah terikat maka patogen akan dirusak oleh histon. Histon H2B mempunyai daya antibakteri terhadap bakteri Gram positive, gram negatif dan terhadap jamur (Goldmann dan Medina, 2013).

\section{KESIMPULAN}

Eosinofil adalah bagian dari sel lekosit yang berperan dalam imunitas alamiah. Struktur sel eosinofil ditandai dengan jumlah lobus inti yang berjumlah 2-6 dengan granula stoplasma terwarna eosinofilik. Sel eosinofl dilengkapi dengan struktur permukaan membran sel yang diperlukan untuk menjalankan fungsinya serta granula sitoplasma yang tersususn atas zat-zat khusus.

Di bidang imunologi klinik, eosinofil 
diketahui terlibat dalam penyakit alergi dan autoimun. Selain itu, Eosinofil berperan dalam imunitas terhadap patogen seperti virus, jamur, cacing dan bakteri. Salah satu mekanisme eosinofil dalam melawan patogen adalah dengan mengeluarkan EET.

Eosinophil extracellular traps terdiri dari anyaman serat DNA (Deoxyribo Nucleic Acid) dan protein granul eosinofil seperti MBP dan ECP.Deoxyribo Nucleic Acid dalam EET berasal dari mitokondria eosinofil ataupun inti sel. Pembentukan EET tergantung dengan adanya radikal bebas dan peningkatan ion kalsium intrasel.

Sifat antimikroba dari EET belum banyak diketahui. Hipotesis yang ada menjelaskan bahwa efek antimikroba EET diperankan oleh histon. Selain itu enzim MBP dan ECP bersifat destruktif terhadap patogen dan jaringan.

\section{DAFTAR PUSTAKA}

Bain, Barbara J., 2011, Blood cell morphology in health and disease, in: Bain, Barbara J.,Bates, Imelda., Laffan, Michael A., Lewis, S. Mitchell., (eds), Dacie and Lewis Practical Haematology, $11^{\text {th }}$ ed, Philadelphia:Churchill LivingstoneElsevier, 94

Blanchard, Carine., Rothenberg, Marc E., 2009, Biology of the Eosinophil, Adv Immunol,101, 81-121

Chun, K. Wong., Cheung, Phyllis F. Y., Wai, K. Ip., Lam, Christopher W. K., 2007, Intracellular Signaling Mechanisms RegulatingTollLike Receptor-Mediated Activation of Eosinophils, Am J Respir Cell Mol Biol, 37, 85-96

Dworski, Ryszard., Simon, Hans-Uwe., Hoskins, Aimee., Yousef, Shida., 2011, Eosinophil and neutrophil extracellular DNA traps in humanallergic asthmatic airways, $J$ Allergy Clin Immunol, 127:1260-6.

Goldmann,Oliver., Medina, Eva., 2013, The expanding world of extracellular traps: not onlyneutrophils but much more, Front Immunol, 3(420), 1-10

Guimaraes-Costa, Anderson B., Nascimento, Michelle T. C., Wardini, Amanda B., Pinto-da-Silva, Lucia H., Saraiva, Elvira M., 2012, ETosis: A Microbicidal Mechanism beyond Cell Death, J Parasitol Research, 929743,1-11

In-Hee, Cho., Ju-Hyun, Gong., Min-Kyung, Kang., Eun-Jung, Lee., Jung, Han Yoon Park., Sang-Jae, Park., Young-Hee, Kang., 2014, Astragalin inhibits airway eotaxin-1 induction andepithelial apoptosis through modulating oxidativestress-responsive
MAPK signaling, BMC Pulmonary Med,14(122), 1-11

Kato, Masahiko., Yamaguchi, Takafumi,. Tachibana, Atsushi., Suzuki, Masato., Izumi, Takashi., Maruyama, Kenichi., Hayashi, Yasuhide., Kimura, Hirokazu., 2005, An atypical protein kinase $\mathrm{C}, \mathrm{PKC} \mathrm{f}$, regulates human eosinophileffector functions, Immunol, 116, 193-202

Maddof, Lawrence C., Kasper, Dennis L., 2008, Basic Consideration in Infectious Disease, in: Fauci, Anthony S., Kasper, Dennis L., Longo, Dan L., Braunwald, Eugene., Hauser, Stephen L., Jameson, J Larry., Loscalzo, Joseph., (eds) Harrison's Principle of Internal Medicine, 17th Ed, New York: McGraw Hill Medical, 750

Morshed, M., Yousefi, S., Sto"ckle, C., Simon, H.U., Simon, D., 2012, Thymic stromal lymphopoietin stimulates the formationof eosinophil extracellular traps, Allergy, 67, 1127-37.

Simon, Dagmar., Hoesli, Susanne., Roth, Nina., Staedler, Simon., Yousefi, Shida., Simon, Hans-Uwe., 2011, Eosinophil extracellular DNA traps in skin diseases, $J$ Allergy Clin Immunol, 127,194-9

Stone, Kelly D., Prussin, Calman., Metcalfe, Dean D., 2010, IgE, mast cells, basophils, and eosinophils, J Allergy Clin Immunol, 125, S73-80

Ueki, Shigeharu.,Melo, Rossana C. N., Ghiran, Ionita., Spencer, Lisa A., Dvorak, Ann M., Weller, Peter F., 2013, Eosinophil extracellular DNA trap cell death mediates lytic release offree secretion-competent eosinophil granules in humans, Blood, 121(11), 2074-83

Warrington, Richard., Watson, Wade., Kim, Harold L., Antonetti, Francesca Romana., 2011, An introduction to immunology and immunopathology, Allergy Asthma Clin Immunol, 7(Suppl 1), 1-8

Yousefi, Shida., Gold, Jeffrey A., Andina, Nicola., Lee, James J., Kelly, Ann M., Kozlowski, Evelyne., Schmid, Inès., Straumann, Alex., Reichenbach, Janine., Gleich, Gerald J., Simon, Hans-Uwe., 2008, Catapult-like release of mitochondrial DNA by eosinophils contributes to antibacterial defense, Nat Medicine, 14, 949-53

Yousefi, Shida., Simon, Dagmar., Simon, Hans-Uwe., 2012, Eosinophil extracellular DNA traps: molecular mechanisms and potential roles in disease, Curr Opinion Immunol, 24(6), 736-9 